\title{
Entrepreneurial Education in a Tertiary Context: A Perspective of the University of South Africa
}

\author{
Anthea P Amadi-Echendu, Magaret Phillips, Kudakwashe Chodokufa, and Thea Visser \\ Department of Business Management, University of South Africa
}

\begin{abstract}
South Africa is characterised by high unemployment levels, a low Total Early Stage Entrepreneurial Activity rate, and a high small business failure rate. Entrepreneurship and small business development is seen as a solution to end unemployment in South Africa. A study to understand how to improve small business support was conducted at the University of South Africa and has shown that alumni are unable to apply theoretical knowledge acquired from their studies. The purpose of this article is to explore the potential of the University of South Africa in becoming more entrepreneurial to address the aforementioned challenges. A desk study that reviewed literature was conducted to identify different constructs associated with an entrepreneurial university, namely entrepreneurial education, research and development, innovation, commercialisation and incubation, and stakeholders. In addition to traditional teaching methods, various alternative approaches can be used to stimulate entrepreneurial education to develop the skills of learners/students. To address these challenges a closer relationship between academia, government, and industry is paramount. It is recommended that universities incorporate entrepreneurial education in all their qualifications, expose students to on-the-job training, assist with the incubation of business ideas that students have, and provide a platform for cross-pollination of knowledge between industry, academia, and government.
\end{abstract}

Keywords: Entrepreneurial university, entrepreneurial education, entrepreneurial learning, alumni, research and development, innovation, commercialisation, incubation, stakeholders, industry, government

\section{Introduction}

The South African government's National Development Plan (NDP) foresees that the unemployment rate should drop from $24.9 \%$ in 2012 to $14 \%$ by 2020 (Zarenda, 2013). To achieve the aforementioned, an additional 11 million jobs must be created in terms of the 2012 of the NDP. The general perception in South Africa (SA), based on government initiatives and industry conversation, is that entrepreneurship and small business development will alleviate the high unemployment rate in South Africa. 
Economists according to Duncan (2012) show that the rates of all levels of Total Early Stage Entrepreneurial Activity (TEA) have dropped significantly compared to the 2013 levels. The TEA rate in South Africa has decreased by 34\% (from 10.6\% in 2013 to $7 \%$ in 2014) and the gap between SA and other sub-Saharan Africa (SSA) countries has widened (Herrington, Kew, \& Kew, 2014). This lower entrepreneurial activity was further confirmed by economist Sharp in 2012, that between 2001 and 2011, there was an estimated 2 million small businesses in SA (as cited by Duncan, 2012). The number increased slightly, to 2.4 million, during the economic boom of 2004 to 2006 , but has shrunk by $18.2 \%$ within the years 2006 to 2011. In 2001, around 250,000 people were involved in starting their own businesses, whereas in 2011, only 58,000 people were trying to do so - a decline of $76 \%$ (Duncan, 2012). Other challenges facing businesses in South Africa are that small businesses do not survive past the first year of trading and the Ministry of Small Business Development (SBD) has put this failure rate as high as $80 \%$ (Fin24, 2014, para. 1).

With these outlined challenges, the question is how can South African universities play a role in solving high unemployment, a low TEA rate and a high small business failure rate. Herrington et al., (2014) explain that there is a need for universities to play an active role to assist in establishing a more entrepreneurial mind-set among students and, more so in SA, where the entrepreneurial propensity in 2014 was 7\%. With the high unemployment rate in SA and no guarantee of stable job opportunities, it is the researchers' view that SA needs to re-orientate students' expectation of the job market and prepare them for a more entrepreneurial mind set.

The University of South Africa (UNISA) conducted a study in 2013 in the City of Tshwane with their alumni owning small businesses including other small entrepreneurs in order to understand how to improve support for small businesses (Masemola, 2013). The findings showed that $41.4 \%$ of the alumni are not adequately equipped with entrepreneurial skills, while 54\% indicated that they need assistance with practical knowledge on how to start a business. A total of $15.3 \%$ of the alumni that were interviewed indicated that they were self-employed. These alumni have the theoretical knowledge but could not apply this knowledge. Small business managers/owners that formed part of the study indicated that they lack financial (36.4\%) and marketing (41\%) skills. Other respondents (69\%) further indicated that they need training for their employees. Most respondents (98.5\%) indicated that it would be beneficial for UNISA to establish a business development centre that provides a one-stop service for small businesses. Additional challenges mentioned in the findings of the study include access to funding, high transport cost, high input costs, lack of technology, lack of effective business reporting, and bad debts.

This article is a desk study that reviewed literature highlighting aspects of an entrepreneurial university. In the researchers' view the building blocks of an entrepreneurial university include entrepreneurial education (EE), research and development (R\&D), innovation, commercialisation and incubation, and stakeholders which will be further discussed in the article. The article aimed to explore the potential of UNISA becoming more entrepreneurial to address the aforementioned challenges.

\section{UNISA as a Higher Education Institution}

UNISA is the largest open distance learning (ODL) institution in Africa and the longest standing dedicated distance education university in the world (University of South Africa [UNISA], 2015). It currently enrols $36 \%$ of all tertiary students in South Africa (International Council for Open and 
Distance Education [ICDE], 2015). Unisa was founded in 1873 and was named the University of the Cape of Good Hope. The institution became the first public university in the world to teach exclusively by means of distance education in 1946. Throughout the years, UNISA was the only university in SA to have provided all people with access to education, irrespective of race, colour, or creed. This vibrant past is mirrored in their massive and impressive database of alumni, some of whom can be found in the most senior levels of society across the world. Given their rootedness in SA and the African continent, UNISA today can truly claim to be the African university in the service of humanity.

UNISA offers an unparalleled range of study choices, ranging from short courses and certificate programmes to three- and four-year degrees and diplomas, as well as post graduate qualifications to over 400,000 current students. UNISA has thus provided access to education to students for 140 years already (UNISA, 2015). According to Salem (2014), there are opportunities for increased entrepreneurship in Higher Education Institutions (HEIs) in order to better prepare students to work in a dynamic, global, and ever changing environment.

\section{Entrepreneurial Education}

Entrepreneurial education (EE) involves developing behaviours, skills, and attributes applied individually and/or collectively to help individuals and businesses to create, cope with, and enjoy change and innovation (Seikkula-Leino, 2008). It involves high levels of uncertainty and complexity to achieve personal fulfilment and business effectiveness (Seikkula-Leino, 2008). EE represents an efficient and cost effective way of increasing the number and quality of enterprising graduates entering the economy (Matlay, 2006). Matlay (2011) observes that there is a shortage of research that focuses on graduate self-employment and/or related new venture creation. Universities have two goals: to create (through research) and disseminate (through education) knowledge (Perreira \& Da Silva, 2003). Universities have different priorities (which include skills development), cultures, norms, traditions, research focuses, and knowledge. Gibb (2012) and Salem (2014) describe entrepreneurial universities as entities that provide environments, cultures, practices, and opportunities that are conducive to encourage and embrace student and graduate entrepreneurship, as well as creating synergy between existing activities in the institution.

To achieve the aforementioned, entrepreneurial learning should be included in a university's strategic plan, policy, and institutional arrangements of the education system, as a means to play a role in addressing problems of society, its commitment to knowledge transfer and exchange, and its focus on graduate employability (Gibb, 2012; Salem, 2014). Entrepreneurial learning is learning that informs the entrepreneur's quest for new opportunities (Franco \& Haase, 2009), while Minniti and Bygrave (2001) view it as how entrepreneurs accumulate and update knowledge rather than developing skills through traditional lectures. Various approaches should be used in order to stimulate entrepreneurial learning (Salem, 2014). It is a driving force for job creation, structural changes, and economic development (Salem, 2014), and provides a means to address poverty in communities (Gibb, Haskins, \& Robertson, 2013).

Ideally an EE should be offered university wide. Streeter, Jaquette, and Hovis (2002) identified two generic models of EE namely the magnet and radiant models of EE. The magnet model of EE is designed to attract students to a variety of relevant courses provided by business schools. The radiant model is aimed at non-business students and focuses on context specific courses and entrepreneurship specialist interest. EE is increasingly offered in faculties that are not directly related 
to business (Matlay, 2011). This may include business training for professionals like doctors, pharmacists, and other professionals who start their own practices with knowledge of their field, but limited knowledge of how to run a business. However, regardless of where the business training is offered, it should build future enterprise oriented students. Business training becomes even more important in the light of unemployment, which includes unemployed graduates. There is also a general shortage of research that links EE to the needs of future graduate entrepreneurs (Matlay, 2011).

Universities can assist in establishing a more entrepreneurial mind-set among students, which will assist them to re-adjust their expectation of the job market (Wong, Ho \& Singh, 2007). Formal (individual development process) and informal approaches (work-related context which is considered to be a collaborative process) to EE contribute in different ways to the development of enterprising students, both within and outside university settings (Matlay, 2011). Academic research may take the form of formal activities such as collaborative research, contract research and consulting, or informal activities such as ad hoc advice and networking with practitioners (Bekkers \& Bodas Freitas, 2008; Perkmann, Tartari, McKelvey, Autio, Broström, D’Este, \& Sobrero, 2013). The environment puts pressure on universities to enhance the student experience (Gibb \& Haskins, 2014). Programmes like research exchange and internship facilitate and support student and staff mobility between the external environment and academia (Byrnes, Paez, Blacker, Jackson, \& Dwyer, 2010). An entrepreneurial university also supports international mobility of students and staff (Gibb et al., 2013).

Traditionally, universities have been involved in knowledge delivery but should also be concerned with the use of this knowledge (Gibb \& Haskins, 2014). These traditions include teaching students in a class room with written formative and summative assessments to test competency of the learning outcomes per curriculum. Laursen and Salter (2004) claim that the work of universities rarely translate into new products and services for industrial organisations. However, increased universityindustry interaction is often based on the expectation that this interaction can increase the rate of innovation in the economy (Spencer, 2001). The pressure for universities to become part of the economic value chain encourages wider discussion as to how universities organise, influence, and use the knowledge flows (Gibb \& Haskins, 2014). Universities should train and develop their staff and students in data literacy to enable them to deal with the vast amount of information available on the web. Converting data into intelligence assist in developing critical thinking and problem-solving skills. This, in turn, may translate ideas into possible small business opportunities.

Small businesses, on the other hand, also need to consider the best sectoral pattern for interaction with a university in order to assess whether it is appropriate for their needs (Bekkers \& Bodas Freitas, 2008). Academics employed as consultants in businesses can co-produce knowledge, services and products through research, businesses can expose their staff members to academic programmes, and patents and licensing can be scanned for ideas (Bekkers \& Bodas Freitas, 2008). Businesses would generally prefer to work with researchers who have a high number of published patents, or those who have authored or co-authored a high number of articles (Bekker \& Bodas Freitas, 2008).

\section{Research and Development}

In the current era of the 21 century a business's innovation performance is linked with its research and development (R\&D) capacities inside the business (Wanzenböck, Scherngell, \& Fischer, 2013). 
Common measures for the establishment of successful R\&D initiatives are R\&D personnel, R\&D expenditure, regularity of R\&D activities, and the establishment of a dedicated R\&D department (Wanzenböck et al., 2013). R\&D intensive businesses invest large amounts of capital into R\&D activities because their R\&D activities are incorporated into the business's strategy (Wanzenböck et al., 2013). Businesses with research-field specific experience and competences are able to benefit from a specific knowledge base that enhances their absorptive capacity, i.e. their ability to learn effectively from the environment and from the work of others (Tether, 2002), allowing them to better exploit external knowledge and achieve valuable outcome of their own R\&D activities (Wanzenböck et al., 2013). Businesses that invest much in R\&D are more prone to have absorptive capabilities to learn and interact with universities (Cohen, Nelson \& Walsh, 2002). The influence of public research on industrial R\&D is found to be disproportionately greater for larger businesses and for start-ups than for other types of businesses (Cohen et al., 2002). Small businesses are less inclined to conduct collaborative and contract research in order to access university knowledge due to fewer financial and skills resources (Bekkers \& Bodas Freitas, 2008). Furthermore, small and new businesses have fewer internal resources, and therefore have a greater need for cooperative agreements (Tether, 2002).

Combining the expertise of unrelated fields may lead to new and creative insights as well as significant collaborations and partnering (Wanzenböck et al., 2013). Publications, participation in conferences, and collaborative research are particularly important in R\&D intensive industrial activities and together with contract research are the best forms of knowledge transfer (Bekkers \& Bodas Freitas, 2008). Knowledge acquired by the university would need to be adapted according to business' specific needs (Bekkers \& Bodas Freitas, 2008) through academic engagement. Academic engagement is defined as knowledge-related collaboration by academic researchers with non-academic organisations (Perkmann et al., 2013). It is also referred to as informal technology transfer, even though most interactions tend to be formalised by means of contracts (Link, Siegel, \& Bozeman, 2007). Knowledge can also be transferred through joint research projects, training, jointly supervising masters and doctoral candidates (academic research), and consulting (Arvanitis, Kubli, \& Woerter, 2008). A key driving force for knowledge transfer is moving knowledge from academia to industry (Ankrah, Burgess, Grimshaw, \& Shaw, 2013). Integrating research into teaching and learning is useful as it updates the content of programmes (Salem, 2014).

\section{Innovation}

Universities are becoming an increasingly important component of the national innovation system (Wong et al., 2007). Innovation is an outcome from entrepreneurial and enterprising behaviour (Gibb, 2012). Linking patterns of information from various sources forms the basis of innovation and new business opportunities (Vaghely \& Julien, 2010). Innovation can assist to differentiate a business' products as well as to improve their competitive position in the market (Milesi, Petelski, \& Verre, 2013). Innovation and knowledge are key factors affecting the competitiveness of businesses and countries (Milesi et al., 2013). An innovation has a direct and indirect value. Direct value refers to what users and producers derive directly from its production and use, while indirect value is found in the production and use of substitute and complementary goods and services (Tether, 1998). Businesses that are part of a bigger group, international businesses and newly established businesses are more likely to be innovators (Tether, 2002), while middle-sized businesses are less innovative (Dolfsma \& Van der Panne, 2008). This becomes relevant for R\&D and work integrated learning for students and staff at entrepreneurial universities. 
Collaboration with universities in mature and emergent industries differs in terms of their market and technology instability, role of networking, and collaboration for innovation development (Bodas Freitas, Marques \& Silva, 2013). Networks contribute significantly to the innovative capabilities of businesses by exposing them to a fresh source of ideas, enabling fast access to resources, and enhancing the transfer of knowledge. Three models of innovation in which this knowledge transfer takes place have been specified (Tether \& Tajar, 2008:727). Firstly, in a traditional model of innovation, the business generates, develops and commercialises ideas. Knowledge for the innovation may transfer from an external source without the source even being aware that this information is being taken. Secondly, where innovations are outsourced, innovations are developed externally and then implemented and commercialised by the business. Thirdly, with the open innovation model, the business both commercialises ideas that originated internal and external to the business. Innovation co-operation means active participation in joint innovation projects (including R\&D) with other organisations (Tether \& Tajar, 2008).

According to the systemic view on innovation processes, innovations are created within a complex web of interactions between different stakeholders of the innovation system (Wanzenböck et al., 2013). Cooperating with customers in the development of innovations is likely to occur when the development is complex, or when the market is poorly defined (Tether, 2002). Businesses that cooperate with their customers reduce their ignorance of customer needs; they increase user confidence, and reduce the risk associated with launching the innovation to the market (Tether, 2002). Businesses can often enhance their image and reputation by associating with a prominent organisation or academic institution, and thus share risks (Ankrah et al., 2013). For a university, innovation may include new programme development, new forms of stakeholder relationships, new developments in alumni relations, new approaches to research, new developments from research, and/or new organisational design and governance (Gibb, 2012). Collaborative research by academia with industry can be a powerful source of innovation (Ankrah et al., 2013). However, innovation becomes a central competitive element only when the potential innovator can appropriate its profits (Milesi et al., 2013). Universities are a cheaper resource for innovation than consultants, but all services are less likely to collaborate with universities (Tether, 2002).

\section{Commercialisation and Incubation}

Commercialisation generates academic impact because it constitutes an immediate and measurable market acceptance for outputs of academic research (Markman, Siegel, \& Wright, 2008). To support commercialisation, many universities have established science parks, technology transfer offices and incubators (Clarysse, Wright, Lockett, Van de Velde, \& Vohora, 2005). Science parks connect a range of challenges identified by a university and possible solution providers as part of an open innovation exchange (Sibanda, 2015). Incubators provide a supportive environment for new business ventures (Gibb, 2012). Physical incubators use shared rented office space, business services, support for building networks, professional business support, and finance. Virtual incubators focus on online business and network development support (Gibb, 2012). An entrepreneurial university has strong links with external initiatives such as science parks and incubators (Salem, 2014). A university can provide intellectual resources (such as financial and marketing skills as identified in the UNISA study) to assist in skills development for existing projects, but can also initiate research in order to identify solutions for unresolved challenges. Universities are increasingly moving from their traditional primary role as education providers to a more complex entrepreneurial university model (Wong et al., 
2007). Such universities incorporate the role of commercialising knowledge and actively developing private enterprises.

A knowledge-based economy would require a more significant increase in commercialising indigenous capabilities and technologies. This implies that the focus needs to move to indigenous innovation, rather than absorbing and diffusing technological knowledge from advanced countries (Wong et al., 2007). Incubators can assist to commercialise indigenous capabilities and technologies. The tendency to commercialise university research may cause universities to neglect research which informs their teaching. This is especially the case where commercialisation income substitutes public funds (Arvanitis et al., 2008). Universities may act as incubation facilities to students and staff by stimulating entrepreneurial ideas and creating the link to industry. In this way universities provide network opportunities for new entrepreneurs and could help potential entrepreneurs access financial services (Salem, 2014).

Commercialisation furthermore involves the patenting and licensing of inventions and also academic entrepreneurship (Perkmann et al., 2013). The primary objective of a patent is to generate incentives for businesses to invest in R\&D activities (Milesi et al., 2013). Patents vary in economic importance across different sectors and many patents do not lead to commercially successful products (Laursen \& Salter, 2004). Legal mechanisms are characterised by formal instruments that involve the legal registration of an innovation whereby the innovator obtains temporal exclusive rights to use, and produce or exploit the innovation (Milesi et al., 2013, Griliches, 1998). Many businesses choose to not register a patent as they find it difficult to prove the novelty of their product or process (Milesi et al., 2013). Engineering and natural sciences are strongly represented among institutes with an inclination to patenting (Arvanitis et al., 2008). When applying for a patent, information must be disclosed which provides open access to technical information about the patented invention (Milesi et al., 2013) therefore increasing the risk of their innovation being copied (Cohen et al., 2002).

\section{Stakeholders}

A decision to be entrepreneurial is a process that involves both internal and external stakeholders (Salem, 2014), and includes a wide range of individuals, organisations, institutions, representatives of government, commerce, and the wider community (Matlay, 2008; Salem, 2014). The choice of partners is dependent on business-specific characteristics, the strategy, objectives, innovation efforts and the costs involved (Wanzenböck et al., 2013). Primary stakeholders include students, teaching and research staff, administrators, and managers directly involved with various aspects of EE (Matlay, 2011). Secondary stakeholders include parents of students, alumni, entrepreneurs, and future employers. Tertiary stakeholders comprise of representatives from government, industry, and the wider community (Matlay, 2011). The government's role is to support organisations with policies to accelerate localisation and to help in the development of new products that is based on transferred technology (Oosthuizen, Butala, Böhm, Rebensdorf, \& Gergert, 2014). Academic faculty members are essentially state employees (Wong et al., 2007). In order to grow the formal economy, stakeholders need to help create value inside the informal economy by investing in education, infrastructure, and the development of programmes (Oosthuizen et al., 2014).

Knowledge exchange mechanisms include joint curriculum development and the provision of internship (Byrnes et al., 2010). Universities should build partnerships with organisations to ensure on-going knowledge exchange, in order to incorporate this knowledge into the curriculum of 
university programmes (Gibb \& Haskins, 2014). Organisational partnerships that bring credibility to the institution and joint degree programmes might also be areas of expertise (Brush, 2014). Businesses with different sizes and activities may engage on different forms and levels with universities to solve their problems and build competency (Bekkers \& Bodas Freitas, 2008).

Stakeholder engagement and partnership include engagement with business, alumni, professional bodies, and entrepreneurs (Gibb, 2012). The entrepreneurial role of a university relates to finding innovative strategies to contribute to social, cultural, and community development by focusing on the strength of its relationship with former alumni, and linking graduates with local businesses (Gibb, 2012). Collaboration with universities seems more likely in sectors where technology is developing fast (Bekkers \& Bodas Freitas, 2008). University engagement with disadvantaged communities can include outreach education, a general institutional commitment, and student recruitment from disadvantaged groups, voluntary work, student projects, and experience (Gibb \& Haskins, 2014). Building relationships with small businesses demand closer university ties with the local community and local development agencies (Gibb \& Haskins, 2014). Small businesses have a shortage of skills (know-how), technology and a collective support system (Oosthuizen et al., 2014). An institution can advance and improve itself by enabling stakeholders to play a key role in order to effect change (Gallo, 2012). Universities can offer students and local communities greater ownership of learning (Gibb \& Haskins, 2014).

Pressure with funding has encouraged academics into greater collaboration with industry which provides better resources than the business has on its own (Tether, 2002). Businesses offer universities extensive access to expertise in product development, commercialisation, market knowledge and employment opportunities for university graduates (Tether \& Tajar, 2008; Ankrah et al., 2013). Different stages of economic development and different innovation systems exhibit different patterns of university-industry relations (Bekkers \& Bodas Freitas, 2008; Perkmann et al., 2013). Working with industry will likely yield conflict as to whether results need to be made public and whether research should be applied towards publication or technical application (Bekkers \& Bodas Freitas, 2008; Perkmann et al., 2013) because it may be incompatible or detrimental to the business's strategic intent (Ankrah et al., 2013). There is and will remain a need for continued effort to build and reinforce networks to maximise resources and experience of good practice for continued benefit to the university (Gibb, 2012).

Alumni are described as the most valuable resource for a higher education institution (Tromble, 1998). Universities have a commitment to engage with alumni (Gibb, 2012). It is up to the alumni themselves to embrace their alma mater to develop a lifelong relationship (Gallo, 2012). Alumni have a vested interest in the reputation of their alma mater as it defines the value of their qualification (Gallo, 2012). It is also important to recognise that each alumnus is at a different stage in their relationship with their alma mater (Gallo, 2012). They can provide employment and internships for students or graduates. Employment relates to the transition to jobs for graduates (Gibb \& Haskins, 2014). Universities can build work integrated learning into their academic degrees that should be linked to industry with subsequent internships (Gibb \& Haskins, 2014). Alumni can also be targeted to fund university initiatives that are not supported by government. They represent their alma mater through the contribution they make to society (Gallo, 2012). Mentoring services should be provided to both students and graduates by alumni and other external stakeholders (Salem, 2014). Graduate entrepreneurship is perceived by government as a contributor to sustainable competitive advantage, 
economic growth, and job creation (Matley, 2011). Moreover, incubators spur new small business development which ultimately leads to economic growth and job creation.

\section{Discussion}

Formal learning at UNISA on an open distance education platform often equip students with theoretical knowledge and do not necessarily expose students to a practical application of this knowledge. This is evident in the UNISA study (Masemola, 2013) where alumni indicated that they need practical training with regard to starting a business. Salem (2014) states that entrepreneurial behaviour is supported through extracurricular activities and teaching methods using both formal and informal learning. Research has shown that the curriculums offered by universities are seen as formal learning. Ideas derived for the presented literature above indicates that alumni generally support universities financially, with training, providing jobs to graduates, assisting with research, and mentoring of current students. In South Africa, two volunteers from the University of Kassel in Germany assisted Mechanical Engineering Science students from the University of Johannesburg (Oosthuizen et al, 2014). The students designed a stove that was manufactured in the incubator and assembled by the community in Kokstad, South Africa, to ensure skills transfer. These designs were not sold for profit. At the University of Ljubljana, Slovenia, third year students are invited to attend a Summer School at Mechatronics. During these three weeks, students voluntarily participate to build robots in a FabLab that is made available to the students. These robots are entered into a competition and this initiative has provided a learning tool to raise technological awareness in the local community. The main purpose of this initiative is to accelerate the transition of basic research concepts performed within an academic environment into working aspects for the manufacturing industry while educating prospective engineers in the process (Oosthuizen et al, 2014). UNISA can assist to build infrastructure for similar initiatives to take place with its students. This will boost learning capabilities and could, in the process, build successful businesses which provide employment.

Recognition of prior learning (RPL) may grant a formal course credit to applicants who have presented suitable evidence that their skills and knowledge acquired outside the university are equivalent to students who have completed the formal curriculum, based on the outcomes identified for each course. Experience by itself is not necessarily evidence of learning, or of learning, that is equivalent to what is required in a course. Although this avenue is provided at UNISA, not all colleges participate in this initiative and mostly refer applicants to write the theoretical examination set for undergraduate students who have registered for the relevant module. While certain types of assessments, for example statistics and accounting, can only be meaningfully assessed with a written assessment, many other modules can assess applicants' skills and knowledge by using other platforms, such as interviews or a written portfolio of evidence. Although long distance education institutions have applicants and registered students from all over the world, they may face difficulties in convening panel interviews. Identification and confirmation that the applicant is the one being interviewed or assessed may also be an inhibitor in introducing alternative assessment methods. Tertiary institutions will need to constantly exchange meaningful discussions in this regard to identify suitable assessment methods for long distance education facilities to overcome these challenges. The Northern Alberta Institute of Technology (NAIT) in Canada offers 14 programmes as part of their RPL project whereby students can influence and build theory at the academic institution (NAIT, 2015).

Some professional diplomas and degrees (e.g., lawyers) offer practical training (work integrated learning/articles/pupillage) that has bearing in their theoretical knowledge. Many graduates who 
obtain professional qualifications will start their own practices and/or businesses which need to be managed. Over and above the discipline-specific qualification (knowledge) that medical doctors and pharmacists require, among others, elements of starting and maintaining their own businesses may be included in the curriculum. This additional knowledge will equip professionals with the required skills to understand business-related requirements.

Informal learning on the other hand may include incubators, stakeholder engagement and R\&D activities. Rather than developing skills through traditional lectures, various approaches could be used in order to stimulate entrepreneurial learning (Salem, 2014). Businesses (industry) can provide internships, mentoring, job shadowing, and temporary employment during studies. Universities can build better academic degree linkages with industry and thus offer more internships (Gibb \& Haskins, 2013). This will enable students to acquire the necessary skills and experience to develop individuals in becoming employable graduates. According to the findings from the UNISA study (Masemola, 2013), the alumni of UNISA indicated that they have theoretical knowledge and may not necessarily be able to apply it. This inevitably influences their employability.

Universities should have a mechanism to absorb knowledge, information and experience that has been created in the wider ecosystem (Salem, 2014). This includes using guest lecturers, internships, contract work, and collaborative partnerships. Career councillors and universities collect data from scholars and students with regard to their aptitudes and interests. This information is used to steer and guide individual career choices but is never used to inform higher education institutions for corresponding amendments to existing curricula, or primary and secondary schools for development of specific skills and interests in children to grow a pool of graduates with specific types of scarce resources such as engineers and/or entrepreneurs. Similarly, there may be many other sources of information and knowledge that can be used to update formal learning and child development to equip children with skills during their developmental years. UNISA as a tertiary institution may not be able to bridge the gap alone. This gap may be resolved by means of a closer relationship between academia, government, and industry, referred to as a triple helix nexus (Wong et al., 2007). Industry determines the employability of graduates which the university should deliver at the exit level. The government could, as the custodian of education, assist in developing primary and secondary level curricula that would develop and focus the mind-set of learners from an early age. The government could also make available the different data collected from various stakeholders which can inform role-players in the triple helix, which in turn could influence policy and curricula development.

\section{Conclusion}

This article explored the repositioning of UNISA as an entrepreneurial university by assisting UNISA students to become more entrepreneurial minded. It is clear from the literature that for a university to become more entrepreneurial, stakeholders and resources, such as infrastructure and technology, need to be adequately used and integrated. Some of these enablers are already in existence, but should be better coordinated for more effective use in developing entrepreneurial mind-sets amongst students. This will allow the university to develop entrepreneurs that can contribute to future economic growth in South Africa. Initiatives that could further enhance EE include R\&D, innovation, commercialisation, and stakeholders. In addition to traditional teaching methods, various alternative approaches can be used to stimulate EE to develop the skills of learners. These alternative approaches include, but are not limited to, providing credits for practical application of certain components of the 
qualification; formal introduction of social media, wiki's and online capabilities into learning and assessments; and introducing a greater industry collaboration component into the learning.

The UNISA study (Masemola, 2013) indicated that the UNISA alumni are unable to apply theoretical knowledge acquired in their studies. In fostering a collaborative relationship with industry, internships to students may increase experiential and practical knowledge of such students. This knowledge may enable students to be more employable in the job market and enable other alumni to become more successful entrepreneurs in their own sustainable businesses. This will positively affect the TEA rate, stimulate economic growth and reduce unemployment in SA. Policy makers (government, industry, and universities) can update educational policies and initiatives in developing successful graduates and ensuring the optimal use of resources. This article may also increase awareness amongst industry on the advantages of participating in $R \& D$ collaborative programmes.

To address the aforementioned challenges, universities, and in particular UNISA as the research focus for this article, should provide an environment, culture, practices, and opportunities that are conducive to encourage and embrace student and graduate entrepreneurship. In addition to the traditional approach of knowledge transfer, universities should assist to provide a coherent and integrated landscape to enhance learning. Regrettably many graduates are unemployed. Employability can increase by enhancing knowledge in the form of digital, lifelong and work--integrated learning, and the acquisition of entrepreneurial skills. To meet the goals of the developmental priorities in SA, the lack of resources on the African continent can be overcome by expanding distance education. This can increase educational opportunities to more people, thus providing logistical support across borders. These are characteristics that are associated with an entrepreneurial university. Fetters, Greene \& Rice (2010) described this environment as an entrepreneurial ecosystem where there can be an increase in entrepreneurial spirit, skills, and support systems that together result in increased economic and social benefits.

It is recommended that universities, in their quest of becoming entrepreneurial, can introduce the following initiatives: curriculum changes to include EE in all qualifications; expose students to on-thejob training; establish an incubation centre at the university to assist with the commercialisation of business ideas and products; establish forums between the university, industry and the government; inform cross-pollination of knowledge and efforts; and uniformity among universities should be established for the recognition of prior learning. Similarly, universities should recognise and credit industry experience in their formal qualifications. All of the above create a platform for lifelong learning. An entrepreneurial university is one that does not only place focus on generating a third stream income from commercialisation, but rather equips students to start and grow sustainable small businesses.

\section{References}

Ankrah, S. N., Burgess. T. F., Grimshaw, P., \& Shaw, N. E. (2013). Asking both university and industry actors about their engagement in knowledge transfer: What single-group studies of motives omit. Technovation, 33(2), 50-65.

Arvanitis, S., Kubli, U., \& Woerter, M. (2008). University-industry knowledge and technology transfer in Switzerland: What university scientists think about co-operation with private enterprises. Research Policy, 37(10), 1865-1883. 
Bekkers, R., \& Bodas Freitas, I. M. (2008). Analysing knowledge transfer channels between universities and industry: To what degree do sectors also matter? Research Policy, 37(10),1837-1853.

Bodas Freitas, I. M., Marques, R. A., \& Silva, E. M. D. P. (2013). University-industry collaboration and innovation in emergent and mature industries in new industrialised countries. Research Policy, 42(2), 443-453.

Brush, C. G. (2014). Exploring the concept of an entrepreneurship education ecosystem. Advances in the study of entrepreneurship, Innovative Pathways for University Entrepreneurship in the 21st Century, 24, 25-39.

Byrnes, J., Paez, D., Blacker, J., Jackson, A., \& Dwyer, C. (2010). The future of higher education in the knowledge-based economy: Developing innovative approaches to integrated articulation and credit transfer in Australia. In Proceedings of the International Higher Education Partnerships and Innovation (IHEPI) Conference Budapest: From Higher Education to Innovation: Management and Entrepreneurship in a Changing Market. 91-101. Publikon Publishers/ID Research Lt

Clarysse, B., Wright, M., Lockett, A., Van de Velde, E., \& Vohora, A. (2005). Spinning out new ventures: a typology of incubation strategies from European research institutions. Journal of Business Venturing, 2O(2), 183-216.

Cohen, W. M., Nelson, R. R., \& Walsh, J. P. (2002). Links and impacts: The influence of public research on industrial R\&D. Management Science, 48(1), 1-23.

Dolfsma, W., \& Van der Panne, G. (2008). Currents and sub-currents in innovation flows: Explaining innovativeness using new-product announcements. Research Policy, 37(10), 1706-1716.

Duncan, F. (2012). South Africa's small business problem - why are SMMEs in South Africa struggling to establish a foothold? Retrieved from http://led.co.za/story/2012/05/07/sas-small-businessproblem-why-are-smmes-in-sa-struggling-to-establish-a-foothold

Fetters, M., Greene, P. G., \& Rice, M. P. (2010). The development of university-based entrepreneurship ecosystems: global practices. Cheltenham: Edward Elgar Publishing.

Fin24. (2014). Zulu: Most SMMEs fail in year one. Retrieved from http://www.fin24.com/Entrepreneurs/News/Zulu-Most-SMMEs-fail-20141028

Franco, M., \& Haase, H. (2009). Entrepreneurship: an organisational learning approach. Journal of Small Business and Enterprise Development. 16(4), 628-641.

Gallo, M. (2012). Beyond Philanthropy: Recognising the value of alumni to benefit higher education institutions. Tertiary Education and Management, 18(1), 41-55.

Gibb, A. (2012). Exploring the synergistic potential in entrepreneurial university development: towards the building of a strategic framework. Annals of Innovation and Entrepreneurship, 3. Retrieved from http://www.innovationandentrepreneurship.net/index.php/aie/article/view/16742 
Gibb, A. A., \& Haskins, G. (2014). The university of the future: An entrepreneurial stakeholder learning organisation. Handbook on the Entrepreneurial University as edited by Fayolle, A. and Redfords, D.T. Edward Elgar Publishing Limited, Cheltenham, United Kingdom, 25-63. Retrieved from https://books.google.co.za/books?hl=en\&lr=\&id=jxCgAgAAQBAJ\&oi=fnd\&pg=PA25\&dq=The +university+of+the+future:+An+entrepreneurial+stakeholder+learning+organisation.+\&ots $=\mathrm{k}$ oVlel8WeG\&sig=wQA-vmB4bCMgd5R-

TCE6u5AI70w\#v=onepage\&q=The\%20university\%20of\%2othe\%2ofuture\%3A\%20An\%2oentr epreneurial\%20stakeholder\%2olearning\%20organisation.\&f=true

Gibb, A. A., Haskins, G., \& Robertson, I. (2013). Chapter 2. Leading the entrepreneurial university: Meeting the entrepreneurial development needs of higher education institutions. In Universities in Change. New York, Springer. 9-45. Retrieved from http://link.springer.com/chapter/10.1007/978-1-4614-4590-6 2\#page-1

Griliches, Z. (1998). Patent statistics as economic indicators: a survey. In R\&D and productivity: the econometric evidence, University of Chicago Press, Chicago, 287-343. Retrieved from http://www.nber.org/papers/w3301.

Herrington, M., Kew, J., \& Kew, P. (2014). Global Entrepreneurship Monitor: South African Report 2013. University of Cape Town Centre for Innovation and Entrepreneurship. Cape Town: University of Cape Town.

International Council for Open and Distance Education (ICDE). (2015, October). Growing capacities for sustainable distance e-learning provision. Paper presented at the $26^{\text {th }}$ ICDE World Conference, Opening address: Minister of Higher Education, Sun City, South Africa.

Laursen, K., \& Salter. A. (2004). Searching high and low: What types of business use universities as a source of innovation? Research Policy, 33(8), 1201-1215.

Link, A. N., Siegel, D. S., \& Bozeman, B. (2007). An empirical analysis of the propensity of academics to engage in informal university technology transfer. Industrial and Corporate Change, 16(4), 641-655.

Markman, G. D., Siegel, D.S., \& Wright, M. (2008). Research and technology commercialisation. Journal of Management Studies, 45(8), 1401-1423.

Masemola, M. E. (2013). UNISA small business development hub market scoping analysis. Pretoria, Bureau of Market Research.

Matlay, H. (2006). Entrepreneurship education: More questions than answers? Education and Training, 48(5), 293-295.

Matlay, H. (2008). The impact of entrepreneurship education on entrepreneurial outcomes. Journal of Small Business and Enterprise Development, 15(2), 382-396. 
Matlay, H. (2011). The influence of stakeholders on developing enterprising graduates in UK Higher education institutions. International Journal of Entrepreneurial Behaviour and Research, 17(2), 166-182.

Milesi, D., Petelski, N., \& Verre, V. (2013). Innovation and appropriation mechanisms: Evidence from Argentine microdata. Technovation, 33(2), 78-87.

Minniti, M., \& Bygrave, W. (2001). A dynamic model of entrepreneurial learning. Entrepreneurship Theory and Practice, 25(3), 5-16.

NAIT, (2015). The Northern Alberta Institute of Technology. Retrieved from http://www.nait.ca/programsandcourses.htm?

Oosthuizen, G., Butala, P., Böhm, S., Rebensdorf, A., \& Gergert, A. (2014, July). Open community manufacturing. Paper presented at the SAIIE 26 Conference. Muldersdrift, South Africa.

Perkmann, M., Tartari, V., McKelvey, M., Autio, E., Broström, A., D’Este, P., \& Sobrero, M. (2013). Academic engagement and commercialisation: A review of the literature on university-industry relations. Research Policy, 42(2), 423-442.

Perreira, M. A., \& Da Silva, M.T. (2003). Stakeholders in university education. Paper presented at the 31st Annual Conference of the Production and Operations Management Society. Atlanta, GA.

Salem, M. I. (2014). Higher education as a pathway to entrepreneurship. International Business and Economics Research Journal, 13(2), 289-294.

Seikkula-Leino, J. (2008). Advancing entrepreneurship education in Finnish basic education: the prospects for developing local curricula. In A. Fayolle and P. Kyrö (Eds), The dynamics between entrepreneurship, environment and education (pp. 168-190), Cheltenham, UK: Edwards Elgar.

Sibanda, M. (2015, March). Partnerships for innovation. Paper presented at the Research and Innovation Week 2015. University of South Africa. Pretoria.

Spencer, J.W. (2001). How relevant is university-based scientific research to private high-technology firms? A United States-Japan comparison. Academy of Management Journal, 44(2), 432-440.

Streeter, D. H., Jaquette, J. P., \& Hovis, K. (2002). University-wide entrepreneurship education: Alternative models and current trends (Working Paper \# 2002-02). Department of Applied Economics and Management. New York: Cornell University.

Tether, B. S. (1998). Small and large business: sources of unequal innovations? Research Policy, 27(7), 725-745.

Tether, B. S. (2002). Who co-operates for innovation, and why: An empirical analysis. Research Policy, 31(6), 947-967.

Tether, B. S., \& Tajar, A. (2008). Beyond industry-university links: Sourcing knowledge for innovation from consultants, private research organisations and the public science-base. Research Policy, $37(6), 1079-1095$. 
Tromble, W. W. (1998). Excellence in advancement: Applications for higher education and non-profit organizations. Gaithersburg, MD: Aspen Publishers.

University of South Africa (UNISA). (2015). Institutional information and analysis portal. Retrieved from http://heda.unisa.ac.za/indicatordashboard/default.aspx

Vaghely, I. P., \& Julien, P. A. (2010). Are opportunities recognised or constructed? An information perspective on entrepreneurial opportunity identification. Journal of Business Venturing, $25(1), 73-86$.

Wanzenböck, I., Scherngell, T., \& Fischer, M. M. (2013). How do business characteristics affect behavioural additionalities of public R\&D subsidies? Evidence for the Austrian transport sector. Technovation, 33(2), 66-77.

Wong, P.K., Ho, Y. P., \& Singh, A., (2007). Towards an "entrepreneurial university" model to support knowledge-based economic development: The case of the National University of Singapore. World Development, 35(6), 941-958.

Zarenda, H. (2013). South Africa's National Development Plan and its implications for regional development. Stellenbosch: Tralac. 